\title{
Port of Rijeka as Cruise Destination
}

\author{
Alen Jugovića, Gorana Mudronjaa, Krista Elza Putninab
}

Cruise industry in Europe significantly contributes to the European tourism since many cruise ships visit various European destinations. Europe is the second most visited cruise destination, and the most significant part is the Mediterranean with its most popular ports - Dubrovnik and Venice. Even though the numbers of passengers in Dubrovnik and Venice decreased last year, they are still very attractive destinations for cruise tourists and have some advantages to which the port of Rijeka can look up. The aim of this paper is to analyse the importance of the port of Rijeka as cruise destination as well as to determine its condition and the necessary improvements. The results of the research show that the number of passengers in the port of Rijeka has been increasing over the past few years, which indicates that Rijeka is developing as a cruising destination. To determine the cruise passengers' satisfaction with Rijeka as cruise destination, a survey was conducted among the passengers on cruise ships that visited Rijeka in 2018. The results of the survey show that the passengers were mostly satisfied with Rijeka as cruise destination although there are some aspects that need to be improved such as the offer of souvenirs and shopping in general. Cruise tourists

\section{KEY WORDS}

$\sim$ Cruise tourism

$\sim$ Adriatic region

$\sim$ Port of Rijeka

$\sim$ Cruise passengers

a. University of Rijeka, Faculty of Maritime Studies, Croatia

e-mail: ajugovic@pfri.hr

b. Latvian Maritime Academy, Riga, Latvia

doi: 10.7225/toms.v09.n01.005

This work is licensed under (cc) BY in Rijeka mostly spent money on clothes and accessories, food and beverages, and organised sightseeing. The port of Rijeka has the potential of becoming an attractive cruise destination, but in order to improve, it constantly has to try to satisfy the cruise tourists' demands.

\section{INTRODUCTION}

Cruise industry is becoming increasingly important in passenger transportation every year. Therefore, ever more tourists tend to choose cruising for their holidays. Europe is the second most popular cruise destination chosen by tourists from all over the world, and its offer is quite diverse. European sub-regions differ in terms of the main sights of ports of call, landscapes, average weather temperatures, and cruising seasons. The Mediterranean region is the most popular cruising region in Europe and the Adriatic Sea is the second biggest sub-region of the Mediterranean. The Adriatic has many cruise ports, most of them small ports serving as ports of call.

The port of Rijeka, mainly a cargo port and the third biggest city in Croatia, located in the northern part of the country, has started to develop as cruise port as well. Rijeka is visited by a few cruise ships each season; however, the number is slowly growing every year. Rijeka fulfils many conditions required for becoming a port of call or home port although it has to improve in the certain segments as well. This paper will compare the port of Rijeka with two biggest ports in the Adriatic region - Dubrovnik and Venice, to understand whether it has the potential of becoming an important cruise port. The survey on cruise tourist visiting Rijeka was conducted during 2018 to find out the information about the tourist preferences and consumption at the destination. The rest of the paper is organised as follows: Section 2 gives the literature review, Section 3 describes the cruise industry in Europe, Section 4 analyses the port of Rijeka and the conducted survey, and Section 5 gives the concluding remarks. 


\section{LITERATURE REVIEW}

Researches dealing with the satisfaction of cruise tourists with the destination and their intention to return to the same destination are numerous. Various authors used different ports as samples and applied different approaches. Andriotis and Agiomirgianakis (2010) researched the motivation and satisfaction of cruise tourists in the port of Heraklion and their willingness to return to the same destination. Research findings have shown that the main motive for cruise tourists arriving at the port of Heraklion is the exploration of culture. Generally, in the Mediterranean destinations, tourists are primarily motivated to explore cultural sights opposed to the Carribbean, where they mostly like to enjoy the sunshine and the sea. The second part of their research was focused on tourists' satisfaction with the destination. The research results showed that tourists were mostly satisfied with the port of Heraklion, while the aspect of the tourists' stay in the port could be improved. Thus, the tourists expressed the desire for a longer stay at the destination in order to see the places of interest. The high level of tourist satisfaction with the destination has a positive effect on their desire to return. In their work, Qu and Ping (1999) researched the cruise tourists' motivation and satisfaction at the destination Hong Kong. The most common motivating factor for visiting this destination was "escape from normal life" followed by "social gathering" and "beautiful environment and scenery". Most cruise tourists were between 18 and 45 years old, which is considered very young cruise tourism population. Furthermore, most respondents were willing to participate in cruising again. Similar research was conducted by Brida, Garrido, and Devesa (2012). The authors researched the satisfaction of cruise tourists in the port of call Cartegna de Indias. The results show that tourists are mostly satisfied with the destination; however, there is room for improvement, primarily in the infrastructure and shopping experience. Most tourists would return to the same destination and recommend the destination to their friends. Teye and Leclerc (1998) researched the cruise tourists' satisfaction with services in the North American area. The results show the cruise tourists' satisfaction with the services provided. Furthermore, the results enable viewing the satisfaction in different segments of the cruise services and help to explain the growth phenomenon that occurred in the cruise market. Cruise tourists were satisfied most with cabin service, while the shore tours received the lowest rating. Ozturk and Gogtas (2016) researched how different attributes of a destination affect tourists' satisfaction with the destination and their willingness to return or recommend the destination to their acquaintances. The destination explored was Honolulu, Island of Oahu, Hawaii. The research findings confirm that there is a relationship of tourist satisfaction with the intention to return to the location or to recommend the destination to acquaintances. The most important attributes that meet the needs of tourists were the high level of services at the port, safe and smooth means of navigating the island, shopping, and a wide range of food and restaurants. The results also showed that the prices of the goods and services contribute to the satisfaction of tourists.

Sanz Blas and Carvajal-Trujillo (2014) researched how a portof-call's image influences the cruise tourists' satisfaction with the destination and what impact it has on cruise tourists' loyalty. The sample used were cruise tourists in the port of Valencia. The results show that the image has a positive effect on destination satisfaction, which again has a positive effect on behavioural intentions as well. It was researched whether the tourists who have a positive image of a destination return to the destination or recommend it to others. The authors also provided insights to destination managers to improve their destination offer. Chang, Liu, and Roh's (2016) research path went toward developing a measurement scale for evaluating cruise travellers' expectations and for examining cruise tourists' satisfaction before and after visiting Incheon. The tourists were mostly satisfied with the culture and exploration of the destination. Furthermore, they were less likely to revisit the destination Incheon, but were willing to recommend the destination to acquaintances. In their work Testa, Skaruppa, and Pietrzak (1998) researched the relationship between employee satisfaction and customer satisfaction. The findings show that there is a relationship between the two parties, and that travel agencies could benefit from improving employee satisfaction with the company they work for, with their supervisor, and with the work environment. The relationship between tourists and the local community on one hand, and tourists and service personnel on the other was investigated in many papers. However, the authors Huang and Hsu (2010) find that the relationship between the tourists themselves has not been sufficiently investigated and are trying to provide new insights into the topic. They investigated the extent to which the quality and quantity of interactions among tourists had an impact on their cruise experience. The results show that customer relationship quality is a more important factor than quantity. It also points to the strong impact of customer-to-customer interaction on customer experience in cruising tourism overall and is thought to be one of the marketing strategies for the business. The authors believe that the interaction among tourists does not have to be accidental, but can be partially controlled by businesses that can encourage communication among tourists and, thus, create a better service. Various researches provide a quality insight into the topic and can give good guidelines for further research.

\section{CRUISE INDUSTRY IN EUROPE}

The cruise industry significantly contributes to the European economy. According to the figures released by Cruise Lines International Association, the cruise industry in 2017 
contributed to the European economy with 46.86 billion EUR. This represents an increase of $16.9 \%$ in comparison with the previous number released in 2015 . Europe is the world's second most popular cruise destination, just after the Caribbean, and 6.5 million passengers embarked on cruises from European ports in 2017, which is by 6.1\% more than in 2015 (Clia Cruise Lines, 2018). The Mediterranean accounted for more than a half of Europe's deployment capacity market share in 2017 (The FloridaCaribbean Cruise Association, 2018). The Mediterranean region, in general, can be divided into four sub-regions (Žlak et al., 2016):

- The western Mediterranean
- The eastern Mediterranean
- The Adriatic Sea
- The Black Sea

The Adriatic is the second biggest Mediterranean region in terms of cruise activity, hosting $17.2 \%$ of the total passenger movements and $21.4 \%$ of the total cruise calls in the Mediterranean and its adjoining seas (MedCruise, 2017).

\subsection{The Adriatic Cruise Region}

The Adriatic Sea is located in the northernmost part of the Mediterranean Sea and is surrounded by Italy, Slovenia, Croatia, Bosnia and Herzegovina, Montenegro, and Albania. It is the second biggest cruise region in the Mediterranean, hosting 2,596 cruise calls in the year 2017, as can be seen from the following Table 1.

Table 1.

The total cruise traffic in the Mediterranean region in 2017.

Source: Cruise activities in MedCruise Ports (MedCruise, 2017)

\begin{tabular}{lllll} 
Region & Total Cruise Pax. & Total Cruise Calls & Home In/Out Pax. & Transit Pax. \\
\hline $\begin{array}{l}\text { Western } \\
\text { Mediterranean }\end{array}$ & $19,721,802$ & 8,383 & $5,468,259$ & $14,253,515$ \\
\hline Adriatic & $4,447,033$ & 2,596 & $1,564,711$ & $2,882,322$ \\
\hline $\begin{array}{l}\text { Eastern } \\
\text { Mediterranean }\end{array}$ & $1,740,289$ & 1,141 & 480,901 & $1,259,388$ \\
\hline Black Sea & 6,449 & 19 & 460 & 5,989
\end{tabular}

The most important ports of the Adriatic region are located in Italy and Croatia, which are followed by Greece, Montenegro and Slovenia (Risposte Turismo, 2017). The areas have both large ports with special facilities for cruises, and small ports without the facilities. However, most of the ports are small ports, mainly for yachts and very small vessels, with no special berths for cruise ships or passenger terminals. The exceptions are Venice, Koper, Rijeka, Zadar and Dubrovnik, which have berths dedicated to cruisers and passenger/cruise terminals. The size and number of ports are determined primarily by the shape of the coastline and the depth of water (Gdynia Maritime University). However, recently many of the smaller ports have become very attractive and their presence in the itineraries calling at the Adriatic ports is increasing on yearly basis which can be a motive for improvement of the ports and tourist sites as well (Risposte Turismo, 2017). The following picture shows passenger ports located in the Adriatic which have the potential to become (or have already become) a significant cruise port.

Cruise ports should examine whether they should be orientated towards serving as a port of call or home port in the cruise market. A home port is the place where the embarkation

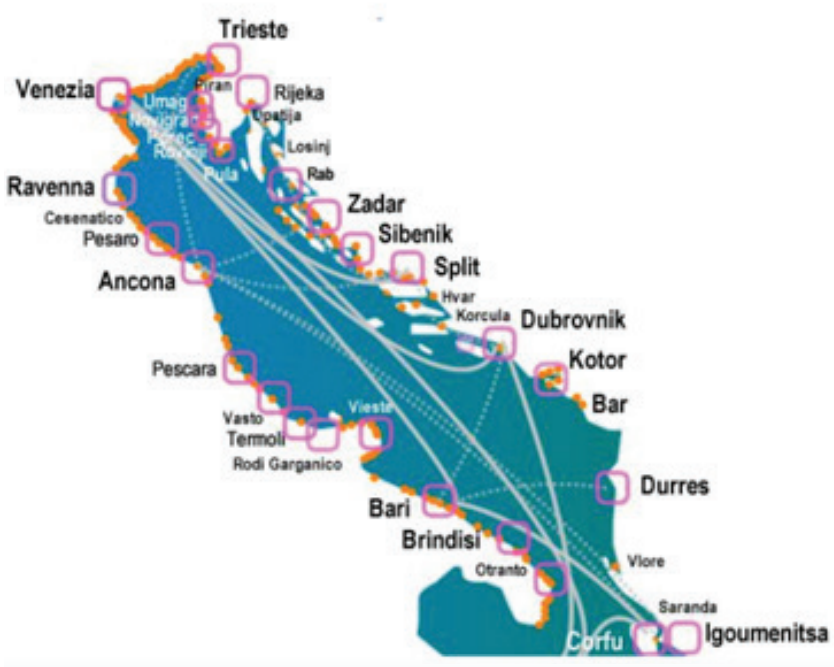

Figure 1.

Adriatic cruise ports, Source: Adriatic Sea Tourism Report (Risposte Turismo, 2017). 
and/or disembarkation takes place at the start and/or end of the cruise. It is also called a base port, head port or main port. Furthermore, a port of call (also called a secondary or destination port) is the place where passengers disembark and then reembark to continue with the cruise (Vojvodić, 2003). There are also hybrid ports, which are considered homeports and ports of call at the same time. These ports usually have perfect conditions for embarking and disembarking including great hinterland connections by road, rail, and particularly by air (Žlak et al., 2016). A cruise port is generally interested in becoming a home port for one or more cruise companies. This is due to the high economic impact of this development on the port and the port-related city. In fact, cruise passengers are estimated to spend six to seven times more money in home ports that at ports of call (Zanne and Beškovnik, 2018).

Even though many Adriatic ports are attractive for many cruise passengers, a relatively small number of ports fulfil all the conditions needed for a home port, such as: location, conception, services. Starting ports location in a cruising system is one of the most important factors of service quality. The port should be near an international airport, as the majority of tourists who reach the starting port use charter flights, an interesting town that can offer some attractive places to visit, and a city centre where tourists can have at their disposal the sightseeing of the town while waiting for cruise to begin (Mrnjavac and Črnjar, 2004).

The concept of passenger terminal has to follow the principle of different kind of traffic: dislocation, passenger traffic arriving and leaving the port, bus traffic, car traffic, taxi car traffic etc. The quality of services largely depends on the organisation of customs and other formalities to be based on the same principle as that of airports. Tourists arriving by airplane from very distant places expect their holidays to start at the moment of their arrival at the port. Therefore, starting ports have to offer accommodation services, catering services, shops and entertainment services. As all these facilities favour commerce, ports should have a strong interest to have them well organized in their area because they contribute to the port's enterprises profits.

Ports of call are not required to fulfil so many requests. The most important is to provide adequate berths and other technical elements, parking area for buses and taxis, and road connections. The role of a port of call can only be taken by a port with tourist attractions - cultural and historical monuments, places of natural beauty, entertainment services, etc. in the town or nearby, which are worth calling at the port. As the cruise ship size is constantly growing and many ports have difficulties to follow their dimensions, cruise ships often anchor in the port basin and tourists are taken on shore by smaller ships (Mrnjavac and Črnjar, 2004). The mentioned elements, particularly regarding home port, are not present in many ports in the Adriatic Sea region. Many of the Adriatic ports do not have suitable handling facilities for a large number of cruise passengers (Vojvodić, 2003).

\subsection{The Adriatic Major Cruise Ports}

According to MedCruise statistics, the port of Dubrovnik is the major port of the Adriatic region in terms of total cruise calls in 2017; however, the port of Venice, Italy, has the highest number of cruise passenger movements in the region (MedCruise, 2017). This means that, although Dubrovnik is visited by more cruise ships, they tend to be smaller and with a lower number of passengers than those who stop at the port of Venice. The other reason could be the restriction that the port of Dubrovnik imposed, concerning the number of tourists that can visit the city, because of its concern about the sustainable development. The following table shows the total number of passengers and cruise calls in the major ports of the Adriatic region.

The third biggest Adriatic cruise port in terms of the total number of passengers is the port of Corfu, Greece, but in terms

Table 2.

Major ports in the Adriatic region by number of passengers and cruise calls

Source: Cruise activities in MedCruise Ports (MedCruise, 2017)

\begin{tabular}{llccc} 
Rank & Port & $\mathbf{2 0 1 6}$ & $\mathbf{2 0 1 7}$ & Change 2017/2016 \\
\hline 1 & & Cruise Passenger Movements & $-11.08 \%$ \\
\hline 2 & Venice & $1,605,660$ & $1,427,812$ & $-9.96 \%$ \\
\hline 3 & Dubrovnik & 831,730 & 748,918 & $-9.24 \%$ \\
\hline & Corfu & 748,914 & 679,681 & $-15.65 \%$ \\
\hline 1 & & Cruise Calls & $-11.91 \%$ \\
\hline 3 & Dubrovnik & 639 & 539 & $-11.70 \%$
\end{tabular}


of the total cruise calls, the port of Kotor, Montenegro, ranks third. Venice had a total of 1,427,812 passengers in 2017, while Dubrovnik had 748,918 passengers. These numbers show that Venice can be considered as home port, while Dubrovnik should be considered as a port of call. Even though Venice and Dubrovnik are different kinds of ports, they both serve a huge number of passengers in the Adriatic region and are the the two biggest cruise ports in the region. Both these cities are world-renowned destinations, UNESCO world heritage sites and, thus, major tourist attractions (Žlak et al., 2016). Both cruise passenger movements and cruise calls have decreased in 2017 in comparison with 2016 (Table 2), which can be an indicator of growing attractiveness of different other ports in other regions.

The port of Venice is the leading home port in the Adriatic and benefits as a popular cruise start and ending point because of availability of an international airport, air connections and reliability of air transport (Venice Port Authority). It has two international airports in the vicinity and two more airports at less than an hour drive (Žlak et al., 2016). Venice is well connected also by rail transport with other important international airports. For example, Venice is 2.5-hour train ride from Milan, and 3.5-hour train ride from Rome (Interrail). This easily accessible location combined with world-renowned tourist attractions are the most important aspects for qualifying as a home port. However, Venice is a highly visited city in general; the city now receives around 30 million tourists per year, disgorged into the narrow streets and small squares. Therefore, it is mostly overcrowded, especially in the summer months, but not only because of cruise passengers (Zanne and Beškovnik, 2018).

The port of Dubrovnik is the second most visited port in the Adriatic region, and its status could develop from a port of call to a hybrid port in the future. It offers a great historical tourist destination as well as the opportunity for embarking and disembarking passengers. Dubrovnik is considered one of the most prominent tourist destinations in the Mediterranean, mostly because of its sublime location and as one of the world's most magnificent walled cities. The main attractions are the charming pedestrian-only old town with aristocratic palazzi and Baroque churches, contained within medieval fortifications and the rocky coast of the Adriatic Sea.

Compared with Venice, Dubrovnik has only one international airport 23 kilometres away from the city. The nearest international airports are Tivat, which is at a 2-hour drive, and Split, which is at a 3-hour drive from Dubrovnik. Compared to the airports in the vicinity of Venice, the airports near Dubrovnik are very small, operating only few flights a day. Regarding inland transportation, there are no trains connecting Dubrovnik with the hinterland; therefore, the only option is a bus or driving by car. These aspects combined make the port of Dubrovnik to qualify as a port of call.

\section{PORT OF RIJEKA}

Rijeka is the third biggest city in Croatia and has always been a transit centre for tourists. Its location is near the peninsula of Istria, town of Opatija, islands of Krk, Cres and Lošinj, towns of Crikvenica and Novi Vinodolski, which all serve as important tourist centres. The port of Rijeka is the largest port in Croatia, with a cargo throughput of $13,404,784$ tonnes, mostly oil, general and bulk cargo, and 260,375 TEUs in 2018 (Port of Rijeka Authority, 2018). The port of Rijeka also has passenger and high-speed lines to the nearby islands. Even though Rijeka is mainly a cargo port,

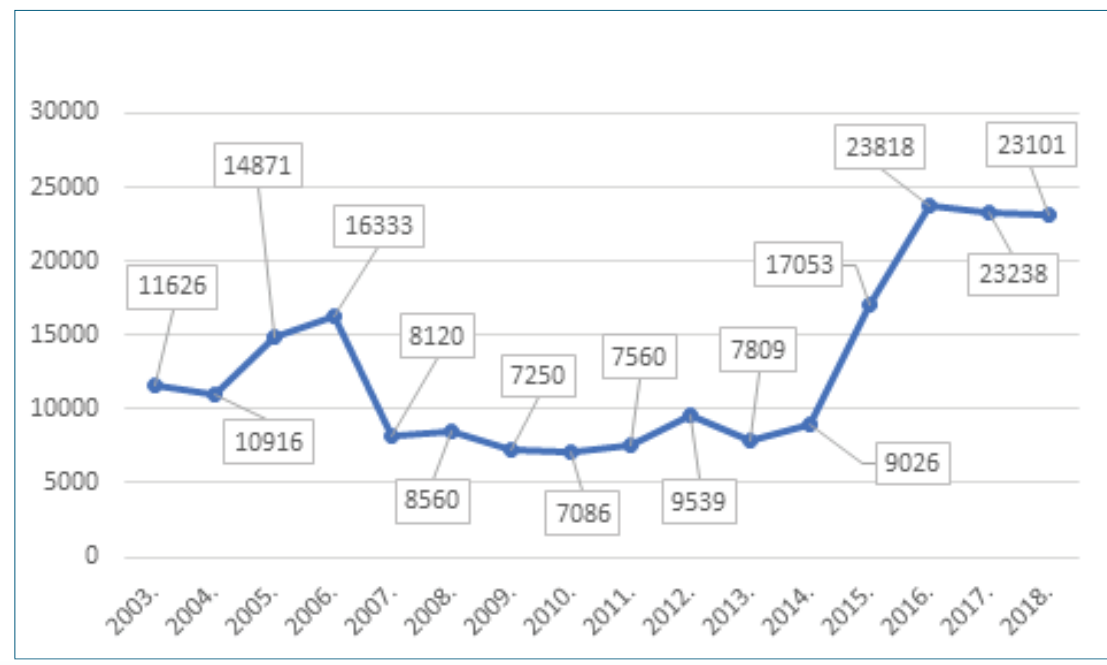

Figure 2.

Number of passengers in the port of Rijeka, Source: Traffic statistics (Port of Rijeka Authority, 2018). 
it is starting to develop as a port of call for cruise ships. Rijeka served as a port of call for 15 cruise vessels in 2017 for the 12,656 cruise passengers visiting Rijeka as part of their cruise itinerary (MedCruise, 2017). The following figure shows the total number of passengers in the port of Rijeka on cruisers and sailboats.

The total number of passengers during the observed years was increasing, which shows that Rijeka has been improving as a passenger destination. If Rijeka wants to improve its status and become a home port or a popular cruise port of call, it has to fulfil certain conditions. These conditions include:

- International transport connectivity

- Disposal with adequate berths and technical elements

- $\quad$ Easy public transportation access from the port to the city and main places of interest

- Tourist attractions, such as cultural or historical monuments, natural beauty or other type of entertainment.

Port of Rijeka Authority has plans for further port infrastructure development in terms of cruise shipping; however, it is also necessary to analyse if the city of Rijeka fulfils the requirements for a popular tourist destination. Rijeka has its own international airport, located approximately 30 kilometres from the city. There are other international airports near Rijeka, such as Zagreb at less than a 2-hour drive, Zadar at a 3-hour drive, and the small airport of Pula at just a 1.5-hour drive from Rijeka. These airports are more of charter airports than main transport hubs, and that is the reason why flights landing at Rijeka airport tend to be much higher in prices than those departing and arriving to and from Italy. If compared with Venice, this aspect makes Rijeka less desirable as an embarking and disembarking port.
Although the port is right next to the city centre with pedestrian-only promenade, historical buildings and churches, waterfront with many cafés and a medieval fortress on top of the city, Rijeka is a more industrial city than a tourist destination. On the other hand, Rijeka is well located for day-trips to many popular attractions in Croatia, such as the Plitvice Lakes, Opatija Riviera, the world's smallest town of Hum, beautiful Mediterranean coastal cities of Rovinj and Pula, and the neighbouring island of Krk.

Croatian cruising tourism is an increasingly important component of the economy; however, a large amount of work is still required on its development and attracting new and the current guests (Jugović et al., 2017). In order to analyse and gather information about the cruise tourists' satisfaction and their money spent at the destination Rijeka, the Faculty of Maritime Studies of the University of Rijeka conducted a survey concerning the consumption and activities of passengers on cruise ships that visited Rijeka during 2018. The survey consisted of questions about the general characteristics of passengers (age, nationality, familiarity with destination), about satisfaction at the destination with different categories, and about time and money spent in Rijeka. The survey included 226 respondents, and its main purpose was to obtain the information about passengers' satisfaction and their consumption in Rijeka. Moreover, the purpose was also to determine the strengths and weaknesses of Rijeka as a tourist destination. Many authors (Teye and Leclerc, 1998; Qu and Ping, 1999; Andriotis and Agiomirgianakis, 2010; Brida et al., 2012; Sanz Blas and Carvajal-Trujillo, 2014; Chang et al., 2016; Ozturk and Gogtas, 2016) researched the topic of

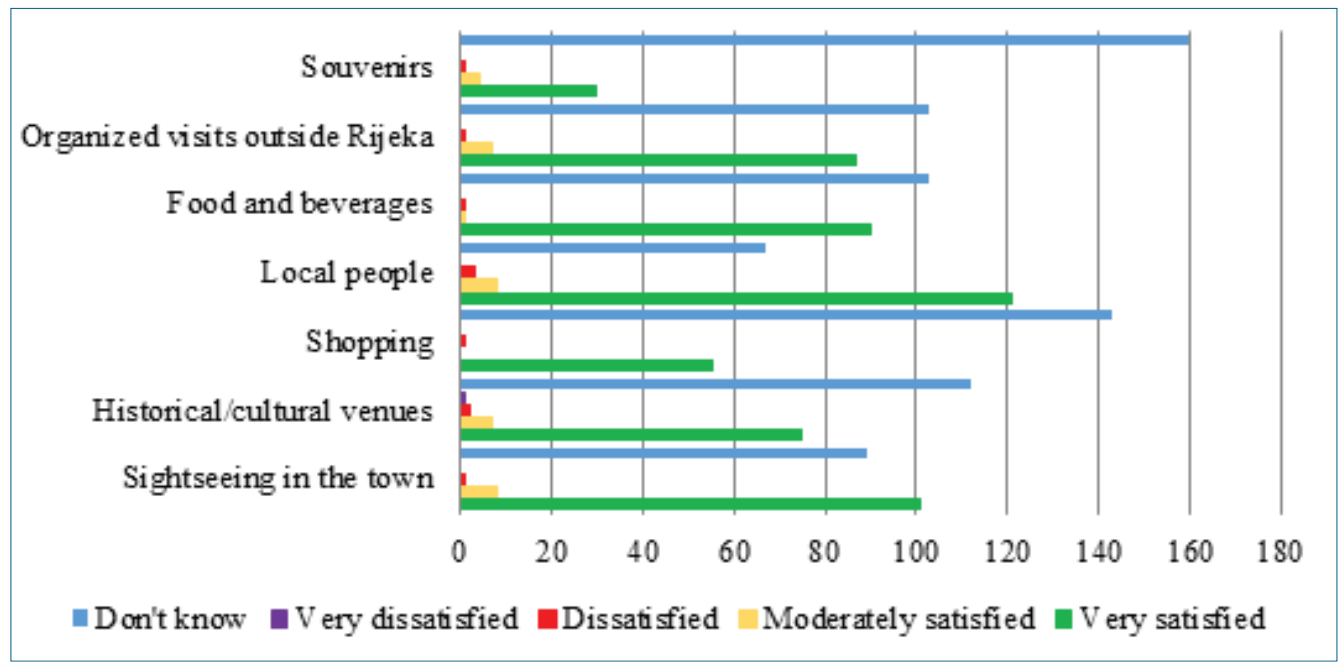

Figure 3.

Satisfaction with destinations across categories, Source: Processed by the authors, based on the survey conducted by the Faculty of Maritime Studies, University of Rijeka. 
cruise passengers' satisfaction with various destinations, while this study also introduces information about the money spent at the destination, which provides a new insight for the destination managers and third parties indirectly involved in cruise tourism (restaurants, souvenir shops etc.).

The profile of cruise passengers who volunteered to participate in the study is as follows: the majority of respondents were in the age group of $60+$ years (30\%), $20 \%$ of respondents in the age group of $41-50$ years, $18 \%$ in the age group of $51-60$ years, $17 \%$ in the age group of $31-40$ years, and $16 \%$ in the age group of 18-30 years. Regarding their nationalities, a majority of the passengers were from the USA (31\%), England (14\%), Germany (9\%), Canada and Australia (each 7\%). When asked about their first visit to Rijeka, $92 \%$ of passengers responded that was their first visit to Rijeka, while $8 \%$ had already visited the destination in past. The survey included the question about the time spent at the destination Rijeka, and a majority of respondents (61\%) spent 1-6 hours at the destination, while only $3 \%$ of the respondents spent 7-9 hours at the destination. The negative feedback was that $36 \%$ respondents spent zero hours at the destination, which provides guidelines to the destination managers to work on attracting more passengers to disembark. From the passengers who went sightseeing, $46 \%$ participated in organized excursions while the rest were exploring the city of Rijeka on their own. The following figure shows the passengers' satisfaction with the destination across different categories.

The overall satisfaction of the tourists was quite high and the results may be considered satisfactory, especially when it comes to the satisfaction with local people, sightseeing in the town, and food and beverages. However, the results indicate that Rijeka should improve its offer of souvenirs and shopping in general. The same kind of study was conducted in the port of Rovinj in 2014 by the Faculty of Maritime Studies, University of Rijeka, and the results were quite similar. The overall satisfaction was high; however, the lowest satisfaction was with shopping and souvenirs (Jugović et al., 2018). Therefore, there is room for development in certain segments and these results should help the port of Rijeka as a destination in the efforts to meet the tourists' needs and expectations. As mentioned above, this study also included questions about the amount of money spent by passengers in Rijeka, and the results are presented in the following figure.

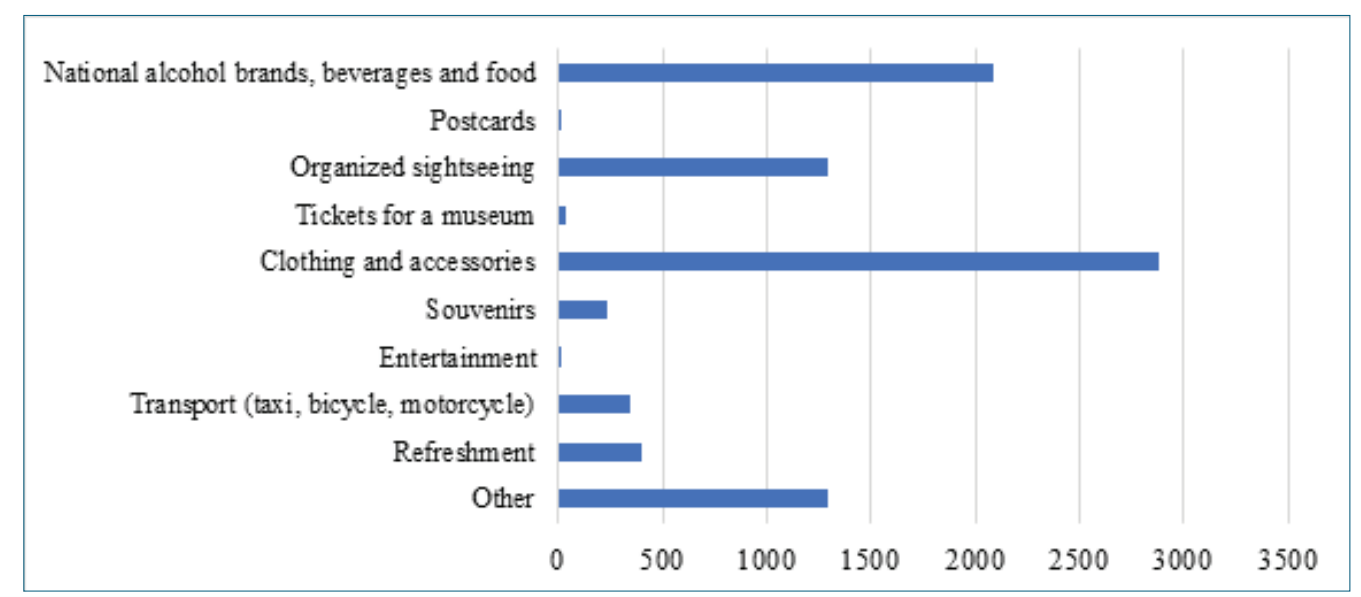

Figure 4.

Cruise tourists' spending by category (in EUR), Source: Processed by authors, based on the survey conducted by the Faculty of Maritime Studies, University of Rijeka.

Cruise tourists were asked to identify how much they spent on different products and services in Rijeka. As it can be seen from the previous figure, the largest amount was spent on clothing and accessories (2,884 EUR), followed by the national alcohol brand beverages and food (2,091 EUR), while organized sightseeing placed third with 1,295 EUR. The smallest amount of money was spent on museum tickets (37 EUR), postcards (14 EUR) and entertainment (10 EUR). The results concerning the money spent per category can give new insights about the tourists' interest and the city of Rijeka's offer. Furthermore, the average spending of cruise tourists in Rijeka amounts to 42.20 EUR per person. The following figure shows the average consumption of cruise tourists by different nationalities. 


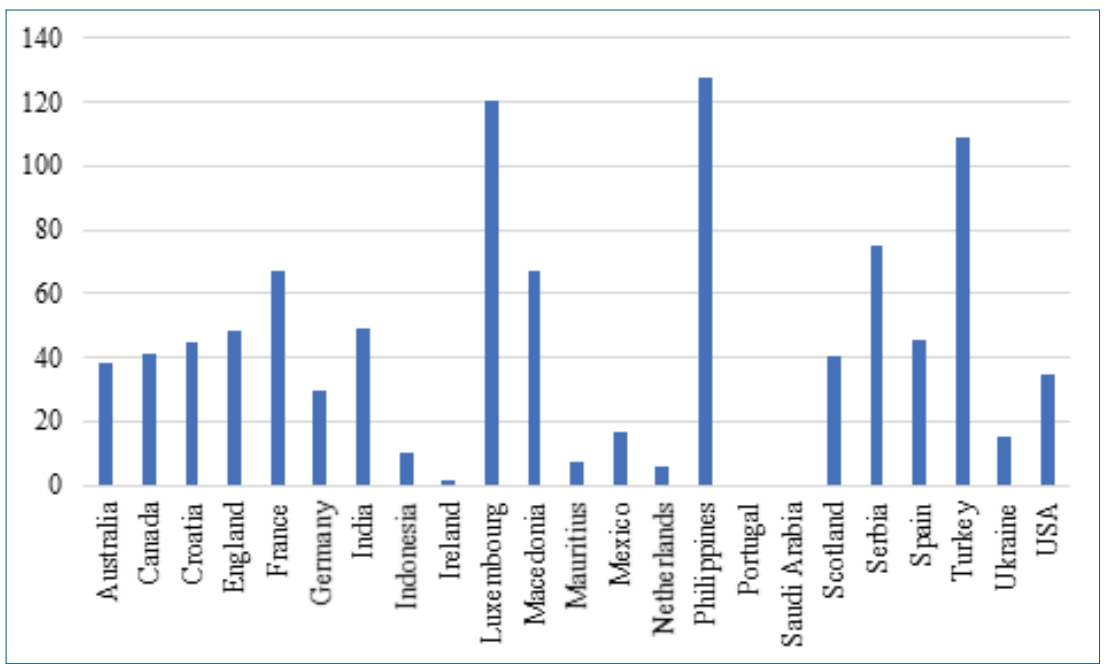

Figure 5 .

Average consumption by nationality (in EUR), Source: Processed by authors, based on the survey conducted by the Faculty of Maritime Studies, University of Rijeka.

The highest spending comes from the Filipino nationality (120 EUR), followed by Luxembourg (120 EUR). Since the majority of passengers came from the USA, England, and Germany, they were observed in detail. The passengers from the USA spent on average 34.92 EUR, passengers from England 48.46 EUR, and passengers from Germany 29.41 EUR. The tourists' spending can have effects on the total GDP of Croatia. Although the consumption in Rijeka is still relatively small, there is room for expansion in the future. Multiplicative effects from cruising industry can occur as well, primarily the direct effects on employment and creation of new value as well as indirect effects on employment and creation of new value of the third parties involved such as restaurants, shops etc. The results of this survey provide new insights into the cruise passengers' preferences and satisfaction with the different segments of the destination Rijeka as well as their willingness to spend money, which can help in further decision-making concerning the creation of tourist offer.

\section{CONCLUSION}

The Adriatic region has a varied offer, and it is an attractive destination for cruise tourists; however, its cruise tourism is still heavily dependent on Venice and Dubrovnik. Both these ports struggle with city congestion, but this does not prevent cruise passengers from visiting these destinations. Venice and Dubrovnik fulfil all the important factors for being home ports or ports of call, and are becoming increasingly popular as cruise destinations each year. Although there are many cruise ports in the Adriatic region, there is none that could compare with Venice and Dubrovnik at the moment.
The port of Rijeka serves mainly as cargo port; however, recently it has started to make its place in the cruising industry. The number of cruise vessels mooring at Rijeka as in-cruise port of call is growing every year. The city of Rijeka fulfils many of the conditions for becoming a cruise port of call; therefore, this research aimed to answer the question to what extent cruise tourists were satisfied with the destination. The research results show that cruise tourists are mainly satisfied with the location and its offer, although there are aspects to be improved such as the offer of souvenirs and shopping in general. Furthermore, cruise tourists mostly spend money on clothing and accessories, food and beverages, and organised sightseeing. The research findings can give valuable insights to the destination managers and third parties in designing their offer. The port of Rijeka has the potential of becoming more attractive to cruise tourists, but it constantly has to try to adapt to the new trends and tourist demands.

However, this study has several limitations. The sample size is sufficient for making general conclusions and giving guidelines, but the representation of findings is limited, and they should be observed as tentative until future studies and results confirm them. The period observed in this study is only one year, which represents a research gap that needs further attention. Therefore, the guidelines for further research can apply to surveys in the future years, gathering more data to make conclusions more accurate.

\section{REFERENCES}

Andriotis, K. and Agiomirgianakis, G., 2010. Cruise Visitors Experience in a Mediterranean Port of Call', International Journal of Tourism Research, 12(4), pp. 
390-404. Available at:

https://doi.org/10.1002/jtr.770.

Brida, J. G., Garrido, N. and Devesa, M. J. S., 2012. Cruise passengers satisfaction: Cartagena de Indias', Benchmarking: An International Journal, 19(1), pp. 52-69. Available at:

https://doi.org/10.1108/14635771211218353.

Chang, Y.-T. et al., 2015. Cruise traveler satisfaction at a port of call. Maritime Policy \& Management, 43(4), pp.483-494. Available at: http://dx.doi.org/10.1080/03088839.2015.1107920.

Clia Cruise Lines, 2018. Contribution of Cruise Tourism to the Economies of Europe 2017. Available at: https://es.cruiseexperts.org/media/2971/2017-europeeconomic-impact-report.pdf.

Gdynia Maritime University, Cruise Port Benchmark Study. Available at: http:// www.smallships.eu/wp-content/download/johann_cruise port benchmark study spreads_02.pdf.

Huang, J. \& Hsu, C.H.C., 2009. The Impact of Customer-to-Customer Interaction on Cruise Experience and Vacation Satisfaction. Journal of Travel Research, 49(1), pp.79-92. Available at:

http://dx.doi.org/10.1177/0047287509336466.

Interrail Railway Map. Available at: https://www.interrail.eu/en/plan-your-trip/ interrail-railway-map.

Jugović, A., Stumpf, G. and Perić Hadžić, A., 2018. Consumption and Activities of Tourists in Cruise Tourism in the Republic of Croatia - Case Study of Port of Rovinj, ICTS 2018 Maritime, Transport and Logistics Science, Conference proceedings. Portorož, Slovenia, pp. 150-154.

Jugović, A., Stumpf, G. and Schiozzi, D., 2017. General Competence Analysis of Management in Nautical Tourism Ports in the Republic of Croatia', Interdisciplinary Management Research XIII. Opatija, Croatia, Postgraduate Doctoral Study program in Management, Hochschule Pforzheim University, pp. 287-296.

MedCruise, 2017. Cruise Activities in MedCruise Ports. Available at: http://www. medcruise.com/sites/default/files/2018-03/cruise_activities_in_medcruise_portsstatistics_2017_final_0.pdf.

Mrnjavac, E. and Črnjar, M., 2004. Croatian North-Adriatic Ports: Passengers Traffic and Environmental Protection. Sustainable Tourism and Transport Development in Adrion. Firenza: Alinea Editrice, pp. 109-121.

Ozturk, U. A. and Gogtas, H., 2016. Destination Attributes, Satisfaction, and the Cruise Visitor's Intent to Revisit and Recommend. Tourism Geographies, 18(2), pp.
194-212. Available at:

https://doi.org/10.1080/14616688.2015.1124446.

Port of Rijeka Authority, 2018. Traffic statistics. Available at: https://www. portauthority.hr/statistike-i-tarife/.

Qu, H. \& Ping, E.W.Y., 1999. A service performance model of Hong Kong cruise travelers' motivation factors and satisfaction. Tourism Management, 20(2), pp.237244. Available at:

http://dx.doi.org/10.1016/s0261-5177(98)00073-9.

Risposte Turismo, 2017. Adriatic Sea Tourism Report. Available at: http://www.adriaticseaforum.com/2017/Public/RisposteTurismo_ AdriaticSeaTourismReport2017.pdf.

Sanz Blas, S. and Carvajal-Trujillo, E., 2014. Cruise passengers experiences in a Mediterranean port of call. The case study of Valencia, Ocean and Coastal Management. Elsevier Ltd, 102, pp. 307-316. Available at: https://doi.org/10.1016/j.ocecoaman.2014.10.011.

Testa, M.R., Skaruppa, C. \& Pietrzak, D., 1998. Linking Job Satisfaction and Customer Satisfaction in the Cruise Industry: Implications for Hospitality and Travel Organizations. Journal of Hospitality \& Tourism Research, 22(1), pp.4-14. Available at: http://dx.doi.org/10.1177/109634809802200102.

Teye, V.B. \& Leclerc, D., 1998. Product and service delivery satisfaction among North American cruise passengers. Tourism Management, 19(2), pp.153-160. Available at: http://dx.doi.org/10.1016/s0261-5177(97)00107-6.

The Florida-Caribbean Cruise Association, 2018. Cruise Industry Overview 2018. Available at: https://www.f-cca.com/downloads/2018-Cruise-Industry-Overviewand-Statistics.pdf.

Venice Port Authority, Port of Venice. Available at: http://www.easeaway.eu/projectpartners/venice-port-authority.

Vojvodić, K., 2003. Cruise Port Positioning - the Case of Korčula, Naše more, 50(5-6), pp. 204-208.

Zanne, M. \& Beškovnik, B., 2018. Assesing Home Port Potencial of Selected Adriatic Ports. Transactions on Maritime Science, 7(2), pp.143-153. Available at: http://dx.doi.org/10.7225/toms.v07.n02.004.

Žlak, B. et al., 2016. Kružna putovanja u Jadransko-jonskoj regiji i njihov potencijal. Naše more, 63(2), pp.56-61. Available at: http://dx.doi.org/10.17818/nm/2016/2.3. 